ZOOLOGIA 28 (1): 1-7, February, 2011

doi: $10.1590 /$ S1984-46702011000100001

\title{
Intraspecific interactions in the mangrove crab Ucides cordatus (Decapoda: Ocypodidae) during the metamorphosis and post-metamorphosis periods under laboratory conditions
}

\author{
Robson Ventura', ${ }^{1,}$; Ubiratã A. T. da Silva²; Antonio Ostrensky ${ }^{3} \&$ Kelly Cottens ${ }^{4}$ \\ ${ }^{1}$ Centro de Desenvolvimento em Aqüicultura e Pesca - CEDAP/EPAGRI. Rodovia Admar Gonzaga 1118, Itacorubi, \\ Caixa Postal 502, 88034-901 Florianópolis, SC, Brazil. \\ ${ }^{2}$ Centro de Estudos do Mar, Universidade Federal do Paraná. Avenida Beira Mar, Caixa Postal 50002, 83255-000 Pontal do \\ Paraná, PR, Brazil. \\ ${ }^{3}$ Departamento de Zootecnia, Universidade Federal do Paraná. Rua dos Funcionários 1540, Juvevê, 80035-050 Curitiba, \\ $P R$, Brazil. \\ ${ }^{4}$ Instituto Chico Mendes de Conservação da Biodiversidade. Avenida Conselheiro Furtado 1303, Batista Campos, \\ 66035-350 Belém, PA, Brazil. \\ ${ }^{5}$ Corresponding author. E-mail: robson.ventura@gmail.com
}

\begin{abstract}
Current efforts for restocking natural populations of the mangrove crab Ucides cordatus (Linnaeus, 1763) in Brazil have focused on developing a methodology for stimulating the metamorphosis of $U$. cordatus larvae at a large scale. The aim of the present study was to compare the mortality rates both in individual and mass conditions, during the induction of metamorphosis of megalopa to juvenile in $U$. cordatus, without the use of mangrove sediment as substrate. Furthermore, the importance of intraspecific antagonistic behavior on survivorship rates during early post-metamorphosis period was investigated. Metamorphosis was induced by the use of water conditioned with conspecific adults (30 indiv. $100 \mathrm{~L}^{-1}$ for 24 hours). In the first assay, megalopae were stimulated into metamorphosis in experimental vials, both under individual and mass rearing conditions. The second assay assessed the interactions between megalopae and first instar juveniles, which have metamorphosed for more than 24 hours. In the third assay, the existence of cannibalistic behavior among first instar juveniles under different experimental densities was investigated. Significant differences between survivorship rates of individuals that metamorphosed under individual and mass rearing conditions were detected. However no cannibalistic behavior between juveniles and megalopae was observed in the second assay. Juveniles reared at a density of 200 indiv. $\mathrm{m}^{-2}$ showed survivorship rates similar to those obtained under individual conditions. Yet 500 juveniles. $\mathrm{m}^{-2}$ treatments showed significantly lower survivorship rates. Intraspecific interactions appear to be an important problem in $U$. cordatus specifically during the metamorphosis, but not during larval and post-larval rearing.
\end{abstract}

KEY WORDS. Cannibalism; juvenile; megalopa; nursery.

Several species of fish and invertebrates are currently showing signs of overexploitation, even while apparently coherent governmental management strategies are in place (Masuda \& Tsukamoto 1998). The mass production of young forms in laboratory, followed by their release directly into areas with depleted stocks, is one of the alternative strategies being developed in different parts of world (BeLL et al. 2008).

Populations of edible crab species, such as Callinectes sapidus Rathbun, 1896 and Portunus trituberculatus Miers, 1876, are in decline in recent decades. Such declines have been tentatively circumvented by experimental restocking efforts. Postrelease in loco analysis have shown that success strongly depends, among other factors, on the age of young forms at the moment of release into the wild (SECOR et al. 2002).
The restocking technology for the Brazilian mangrove crab Ucides cordatus (Linnaeus, 1763) is being developed by our research group since 2001. Currently, the annual production is over 1,000,000 megalopae per season (Silva et al. 2006, 2009). So far, the young forms produced are released during the megalopa phase. Recent studies have indicated that releasing individuals during juvenile phase could be more effective, due to their naturally lower susceptibility to predation by fish, as well as a higher potential to compete with crabs of other species (Ventura et al. 2010a).

However, in order to release more ontogenically advanced recruits, the first key process to be developed is a methodology for stimulating metamorphosis of $U$. cordatus larvae, at a large scale. 
Mangrove sediments have naturally occurring cues known to stimulate the metamorphosis of different species of mangrove crabs (O'ConNor \& GREgG 1998, O'ConNor 2007). Although effective, the amount of mangrove required to induce metamorphosis indoors, and at a large scale, would be so large that problems such as widespread contamination and logistics would make management impracticable.

Simith \& Diele (2008) have shown that the induction of metamorphosis in $U$. cordatus can be obtained using only water, conditioned with chemical stimulus from conspecific adults, without the utilization of sediment. Although the assays conducted by this researcher were developed in a small scale, using individualized experimental units, it is possible that, under mass rearing conditions, a variation of this methodology could achieve satisfactory results, permitting the maintenance of larvae during metamorphosis and during early juvenile phase under laboratory conditions, inside nursery structures. Different kinds of nursery structures are widely used for other crab species: tanks with volumes ranging from 8L (BAYLON \& FAILAMAN 1999) to 8,000L (Dat 1999), hapa net-cages (Rodríguez et al. 2007), or even earth bottomed ponds (MARASIGAN 1999).

In general, growth rates achieved by juveniles in ponds are the highest. However, rearing using indoor tanks and hapa net-cages facilitates the prevention of young forms mortality. The food supplied to crabs in nurseries may include minced fish (HAMASAKi et al. 2002), diets for penaeid shrimp (ZMOra et al. 2005) and Artemia sp (nauplii or adults) (BaYLON \& FAILAMAN 1999, Mann et al. 2001, Quinitio \& Parado-Estepa 2000).

Rearing densities also vary enormously. In nurseries of Scylla crabs, stock densities of 1 to 150 indiv. $\mathrm{L}^{-1}$ were tested using indoor tanks (BAYLON \& FaILAMAN 1999) and 0.1 to 125 indiv.m ${ }^{-2}$ in ponds (Marasigan 1999, Rodríguez et al. 2007). Juveniles of the blue crab C. sapidus were also experimentally cultivated in nurseries using indoor tanks at densities of 2.5 to 40 indiv. $\mathrm{L}^{-1}$ (Zmora et al. 2005). Higher densities were related to lower rates of survivorship, mainly due to cannibalism.

The cannibalistic behavior is considered the most important factor during the nursery period. This problem is especially limiting when the crabs reared, under controlled conditions, suffer asynchronous metamorphosis (QuinItIo \& PARADOEstepa 2000, Zmora et al. 2005). Technologies to decrease mortality rates, related to this behavior, have already been developed involving food supplementation (DuTIL et al. 1997, LuPPI et al. 2001) and the use of artificial substrates (CHEN 1990, Marichamy \& Rajapackiam 2001, Hamasaki et al. 2002, Baylon \& Failaman 1999, Aileen et al. 2000, Zmora et al. 2005).

The goal of the present study was to compare the mortality rates, both under individual and mass rearing conditions, which occur during the induction of metamorphosis from megalopa to juvenile in $U$. cordatus, without the use of a mangrove sediment as a substrate. Additionally, the effect of intraspecific antagonistic behavior on survivorship rates during the early post-metamorphosis period was investigated.

\section{MATERIAL AND METHODS}

\section{Larval rearing}

Larvae for the experiments were obtained from U. cordatus ovigerous females collected in the mangroves in Santo Amaro, Bahia state, Northestern Brazil (1240'29"S 3844'09”W). Collected females were brought to the laboratory, where they were maintained in 1,000 L plastic tanks filled with sea water under controlled environmental conditions (at $26^{\circ} \mathrm{C}, \mathrm{pH} 8$, and 30 psu) until hatching, which occurred without any artificial stimulus. During the larval rearing period, a specific food protocol was provided at each developmental stage, consisting only of microalgae (Thalassiosira sp. and Chaetoceros sp.) for the initial stages and Artemia sp. nauplii from stage zoeae V to the end of the larviculture. The larvae used in the experiments were kept in mass cultivation containers until they reached the desired stage for each assay.

\section{Experimental setup}

The experiments were conducted in an environmental room under controlled temperature $\left(26^{\circ} \mathrm{C}\right)$ and photoperiod $(16: 8$ $\mathrm{h} \mathrm{L} / \mathrm{D}$ cycle). Each experimental unit consisted of a clear plastic container $(100 \mathrm{~mL}$ vial - diameter $6.5 \mathrm{~cm}$, height $7 \mathrm{~cm}$ or 500 $\mathrm{mL}$ vial - diameter $11.3 \mathrm{~cm}$, height $5 \mathrm{~cm}$ ), which was kept on a dark surface, to facilitate the observation of the larvae. The water used in all of our experiments was adjusted to a salinity of 30 psu, filtrated through a 5 micrometer cellulose filter and disinfected using ultraviolet light. Metamorphosis induction procedures followed Simith \& Diele (2008), using water, conditioned with chemical stimulus from conspecific adults, as an inducer. This conditioned water was prepared through the $24 \mathrm{~h}$ immersion of $30 \mathrm{U}$. cordatus adults (males and females in the same proportion) for each1,000 L of seawater, followed by its filtration through a sieve (100 microns) into a sealed container. The water in each experimental container was replaced every 24 hours.

The individuals were placed in the experimental containers either as megalopae or as juveniles, following the different protocol established for each assay. The proportion at which the developmental phases were placed in the containers varied according to the objective of the assays described below. The basic diet used in all experiments was composed of newly hatched Artemia nauplii $\left(0.3\right.$ indiv. $\left.\mathrm{mL}^{-1}\right)$. As juvenile $U$. cordatus cannot swim (Ventura et al. 2008), it was anticipated they would have difficulties preying on live nauplii. Therefore, depending upon the assay, dead Artemia nauplii (killed by freezing) were additionally provided, at the same density.

\section{Metamorphosis under individual and mass rearing conditions}

In the first assay, megalopae were stimulated to metamorphose in experimental vials, both under individual and mass rearing conditions. Three sets of experimental vials were used in this assay. In all sets the megalopae/saltwater proportion was one individual $/ 100 \mathrm{~mL}$. The first set was composed of 
$100 \mathrm{~mL}$ vials containing only one megalopa each. This setup was used to establish the survivorship and metamorphosis rates in the absence of effects exerted by any other individual. The second set used $500 \mathrm{~mL}$ experimental vials which contained five megalopae each (10 megalopae. $\left.\mathrm{L}^{-1}\right)$. Assuming that intraspecific antagonistic behavior could be related to insufficient feeding, the last set also used $500 \mathrm{~mL}$ experimental vials, the same number of megalopae as the second set but also received dead Artemia nauplii in addition to the basic diet (live Artemia nauplii) at a density of 0.3 indiv. $\mathrm{mL}^{-1}$. After 24 hours, dead young forms and metamorphosed megalopae were counted to determine metamorphosis and survivorship rates.

The individual rearing set was performed with 25 replicates and the other two sets with five replicates each. This assay was performed eight times in consecutive days, for a total of 200 repetitions ( 25 replicates $\mathrm{x} 8$ assays) for the first set and 40 repetitions ( 5 replicates $x 8$ assays) for each of the other two sets, for a total sample size of 280 vials.

\section{Interactions between $U$. cordatus juveniles and megalopae}

The aim of this second assay was to investigate the interactions between first instar juveniles and megalopae. Juveniles used in this assay were maintained in a $20 \mathrm{~L}$ container, at a density of 100 indiv. $\mathrm{m}^{-2}$, for 24 hours, before they were transferred to experimental vials. This procedure was adopted to ensure that their exoskeleton has completely hardened and that they were able to display antagonistic behavior to the megalopae.

The assay was conducted with two sets as the control group and two sets as treatment groups. All of them used 500 $\mathrm{mL}$ experimental vials and were fed with the same basic live Artemia nauplii (0.3 indiv. $\left.\mathrm{mL}^{-1}\right)$ diet. The megalopae control group was composed of only five megalopae and the juveniles control group of only two juveniles. Control groups were aimed to provide an indication of background mortality rates in the absence of potential cannibalism between juveniles and megalopae. In the treatment group, both sets were composed of five megalopae and two first instar juveniles in the same vial. The difference between the treatment sets was that one of them received dead Artemia nauplii as supplementary food.

All sets were performed with five replicates. After 24 hours, dead young forms were counted to determine survivorship rates. The assay was performed 5 times in consecutive days, for a total of 25 repetitions ( 5 replicates x 5 assays) for each set, for an overall sample size of 100 vials.

Interactions among first instar $U$. cordatus juveniles

In this third assay, the existence of cannibalistic behavior among first instar juveniles was investigated by varying their den- sity in the experimental containers. The control group was composed of one set of $500 \mathrm{~mL}$ experimental vials, each containing a single juvenile in $250 \mathrm{~mL}$ of water. Two different densities were tested. In the first set, two juveniles were placed in experimental vials containing $500 \mathrm{~mL}$ of water (corresponding to 200 indiv.m ${ }^{2}$ ), same proportion of larvae/saltwater of the control group (one individual $/ 250 \mathrm{~mL}$ ). In the second, 5 first instar juveniles were added to vials with the same water volume (at a density equivalent to 500 indiv. $\mathrm{m}^{-2}$ ). In this assay, only dead Artemia nauplii were provided as food, at a density of 0.3 indiv. $\mathrm{mL}^{-1}$.

All treatments were performed with five replicates. After 24 hours dead young forms were counted to infer survivorship rates. The assay was performed seven times in consecutive days, for a total of 35 (5 replicates $\mathrm{x} 7$ assays) repetitions for each treatment and an overall sample size of 105 tested vials. For this assay it was not possible to perform the control group with 25 replicates, as in the first experiment, given that the experimental availability of first instar juveniles for the tests was limited.

\section{Statistical analysis}

All data were analyzed using the program Statsoft Statistica ${ }^{\circledR} 7.0$, at a $5 \%$ level of significance. Given that the first experiment compared treatments with different number of repetitions and that the Shapiro-Wilk test indicated that the data from the other experiments departed significantly from normality, all analyses were conducted using nonparametric statistics. Survivorship and metamorphosis rates were compared using Kruskal-Wallis tests, followed by multiple comparisons of groups using the Bonferroni Correction, as post hoc tests.

\section{RESULTS}

\section{Metamorphosis under individual and mass rearing conditions}

Survivorship rates of individuals maintained individually were higher than those submitted to mass rearing conditions ( $\mathrm{N}=280 ; \mathrm{H}=29.44 ; \mathrm{p}<0.01)$. However, significant differences were not detected between survivorship rates in the group in which dead Artemia nauplii were used as supplementary food and those observed in the group under mass rearing conditions. No significant differences were detected between metamorphosis rates obtained in all treatments $(\mathrm{N}=280, \mathrm{H}=7.22$, $\mathrm{p}=0.27)$ (Figs 1 and 2).

\section{Interactions between $U$. cordatus juveniles and megalopae}

No significant differences were observed between survivorship rates of megalopae $\left(\mathrm{N}=75^{*}, \mathrm{H}=0 \mathrm{p}=1.00\right)$ and juveniles $\left(\mathrm{N}=75^{*}, \mathrm{H}=0, \mathrm{p}=1.00\right)$ obtained in control groups and

\footnotetext{
* The $\mathrm{N}$ of this analysis is 75 because it compared exclusively the megalopae survivorship rates: 25 replicates of Megalopae control, 25 of Megalopae+juveniles group and 25 of Megalopae+juveniles with food supplementation group. Megalopae survivorship is an absent data for the Juveniles control group. The same logic can be used for the comparison among juvenile survivorship rates.
} 


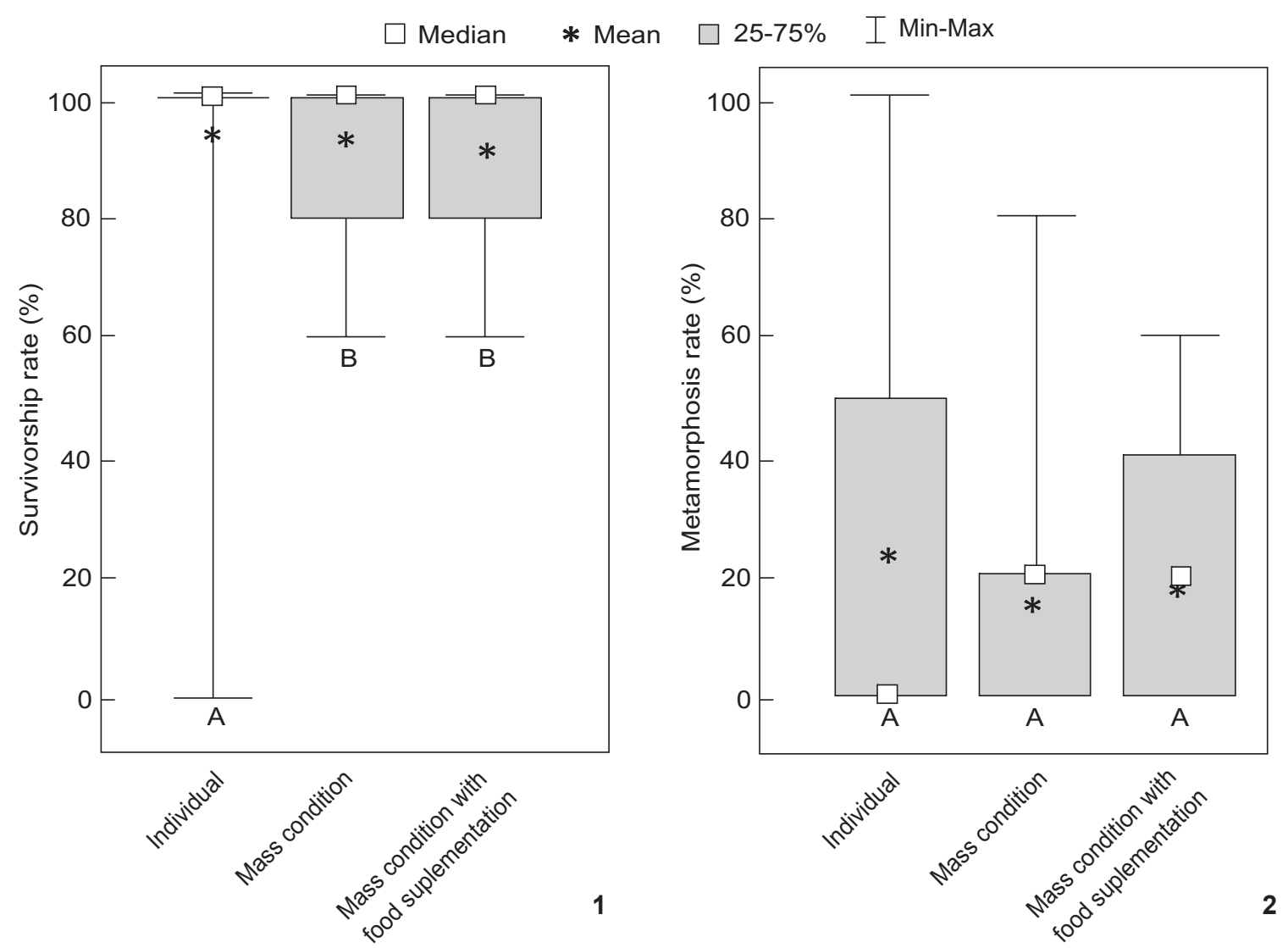

Figures 1-2. (1) Survivorship and (2) metamorphosis rates of $U$. cordatus metamorphosing from larval to juvenile phase under individual and mass rearing conditions, in the presence or absence of supplementary food. Letters under boxes indicate homogeneous groups according to the statistical analysis.

in treatments in which megalopae and juveniles were maintained together, neither in the presence or absence of supplementary food (Fig. 3).

Interactions among first instar $\boldsymbol{U}$. cordatus juveniles

Survivorship rates observed in control group were similar to those observed in the treatment with a density of 200 juveniles $\mathrm{m}^{-2}$. However, treatment in which density was 500 juveniles $\mathrm{m}^{-2}$ showed significantly lower survivorship rates ( $\mathrm{N}=105, \mathrm{H}=8.20, \mathrm{p}=0.01$ ) than those observed in the control group, although, in all cases, at least $40 \%$ of the juveniles survived during the assays (Fig. 4).

\section{DISCUSSION}

The results of the first assay showed significant differences between survivorship rates of $U$. cordatus megalopae metamorphosing under individual and mass rearing conditions. However, the results of the second assay point in another direction, in that juveniles that had metamorphosed for more than 24 hours, thus showing a completely hardened exoskel- eton, do not appear to prey on megalopae. This can be an indication that intraspecific interactions are important sources of mortality of $U$. cordatus specifically during the molting period in which larvae metamorphose to the juvenile phase.

Studies on the importance of intraspecific relations during the settlement process carried out with other crab species have reported that intraspecific interactions play an important role in modulating the survivorship of young forms. In assays conducted with C. sapidus, Moksness et al. (1997) observed that juveniles (instars 3, 5 and 9) prey on megalopae and cause significant mortality, regardless of density and type of substrate (sand or seagrass, in that case). Fernandez (1999) also observed cannibalistic behavior of juveniles (instars 3 and 4) on megalopae of the crab Cancer magister Dana, 1852, reporting that the mean number of individuals consumed by juveniles was affected by both predator size and megalopae density. It is important to note that even the highest predator and prey densities tested by MoKsness et al. (1997) (0.05 and 0.34 indiv. $\mathrm{L}^{-1}$, respectively) and by FerNANDEZ (1999) (0.1 and 0.4 indiv.L ${ }^{-1}$, respectively) were still lower than those used in our assays. That 


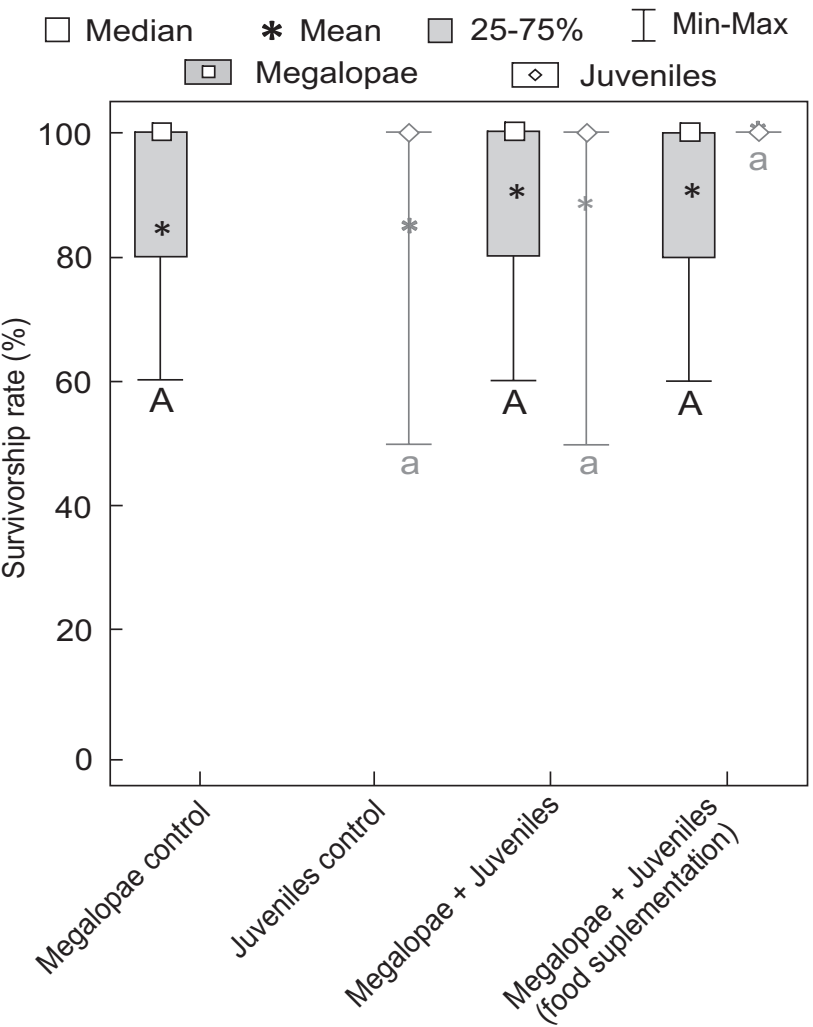

Figure 3. Survivorship rates of $U$. cordatus in the megalopae and juvenile phase reared separately and together, in the presence or absence of supplementary food. Letters under boxes indicate homogeneous groups according to the statistical analysis.

could be an indication that these species are characteristically more aggressive than $U$. cordatus at the same age. However, these studies tested more ontogenically advanced young forms than only first instar juveniles. Therefore, we cannot disregard the fact that more developed $U$. cordatus juveniles may prey on megalopae. For this reason, our findings should not be readily extrapolated to what would occur in rearing tanks containing larvae with highly heterogeneous growth rates, although the coexistence of several ontogenetic stages in the same rearing tank is not common.

The low level of aggressiveness of $U$. cordatus, in relation to other species, was previously reported in the specific case of the megalopa phase. Experiments on larval cannibalism and transport simulation tests, both conducted with $U$. cordatus, showed that survivorship rates of megalopae, maintained at high densities and in stressful situations, are not affected by cannibalism (Ventura et. al. 2008, 2010b). On the other hand, studies about transport under high densities conducted with C. sapidus indicate that megalopae prey on each other when maintained in confined conditions (QuinITIO \& PARADO-EstePA 2000).

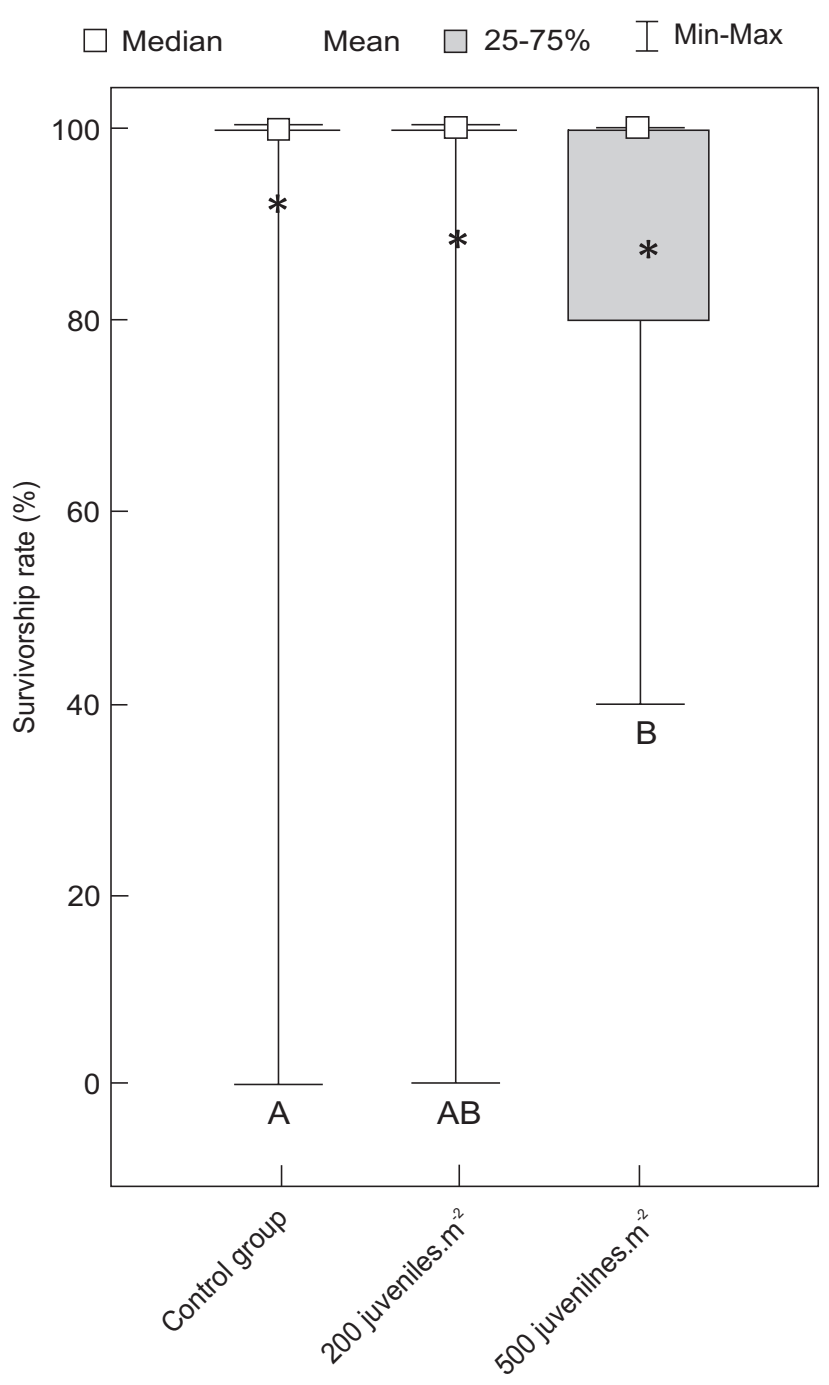

Figure 4. Survivorship rates of $U$. cordatus juveniles reared at different densities. In the control group, juveniles were reared individually. Letters under boxes indicate homogeneous groups according to the statistical analysis.

In the present study, the use of dead Artemia nauplii was tested as a tentative way of avoiding antagonistic intraspecific behavior of newly metamorphosed juveniles on metamorphosing larvae. However, this protocol, in our first assay, does not appear to have a positive effect on survivorship rates. In other crab species, cannibalistic behavior among juveniles is frequently reported, especially by the more developed individuals on younger ones (AILEEN et al. 2000, BAYLON \& FAILAMAN 1999, Luppi et al. 2001, ZMORA et al. 2005).

The results of the last assay indicate that first instar juveniles of $U$. cordatus tolerate densities up to 200 indiv. $\mathrm{m}^{-2}$, with survivorship rates similar to those obtained under individual 
rearing conditions. Even considering that, at a density of 500 indiv. $\mathrm{m}^{-2}$, a significantly lower survivorship than the control group was observed, the results indicate that the use of higher densities of megalopae and juveniles, than those used in other crab species cultures, is possible.

On the other hand, by taking into account that intracohort cannibalism among juveniles is normally related to the molting process (МокSNEss et al. 1997), it is conceivable that the mortality observed could be exacerbated by maintaining juveniles in such conditions during longer periods of time, involving more molting events. Therefore, further studies are needed to determine the most suitable densities, allowing for the maintenance of juveniles in nurseries during periods involving numerous molting events.

Nevertheless, important clues for the development of laboratory nurseries were obtained in this study. Intraspecific antagonistic behavior appears to be a problem during the metamorphosis to the juvenile phase of $U$. cordatus. Studies should be developed to investigate different ways of avoiding mortality during this phase, such as the use of other feeding protocols or substrates. Not withstanding, it seems possible to maintain megalopae and first instar juveniles in the same tanks free of mangrove sediment without significant mortalities. Further studies are needed to investigate if laboratory-produced juveniles can be cultivated until they reach a more suitable age for release into the environment.

\section{ACKNOWLEDGMENTS}

We thank the Government of the State of Bahia and Bahia Pesca S/A for funding this research.

\section{LITERATURE CITED}

Aileen, T.S.; B.H.Y. Zulfigar; Y. Fujir; T. Fukuda \& M. Terazaki. 2000. Culture of Japanese blue crab (Portunus trituberculatus). Tokyo, JSPS/UCC, 29p.

Baylon, J.C. \& A.N. FAILAMAN. 1999. Larval rearing of mud crab Scylla serrata in the Philippines. In: Keenan, C.P. \& A. Blackshaw. Mud crab Aquaculture. Canberra, Aciar, I+98p.

Bell, J.D.; M. Kenneth; H. Leber; L. Blankenship; R. Neil; R. LONERAGAN \& R. MASUdA. 2008. A new era for restocking, stock enhancement and sea ranching of coastal fisheries resources. Reviews in fisheries science 16: 1-9.

Chen, L.C. 1990. Aquaculture in Taiwan. London, Fishing News Books, 273p.

Dat, H.D. 1999. Description of Mud Crab (Scylla spp.) Culture Methods in Vietnam, p. 67-71. In: C.P. KeENAN \& A. BLACKSHAW (Eds). Mud crab Aquaculture. Canberra, Aciar, I+98p.

Dutil, J.D.; J. Munro \& M. Peloquin. 1997. Laboratory study of the influence of prey size on vulnerability to cannibalism in snow crab Chionoecetes opilio (Fabricius1780). Journal of Experimental Marine Biology and Ecology 212: 81-94.
Fernandez, M. 1999. Cannibalism in Dungeness crab: the effects of predator-prey size ratio, prey and predator densities, and habitat type. Marine Ecology Progress Series 182: 221-230.

HAMASAKI, K.; M.A. SUPRAYUdi \& T. TAKEUCHI. 2002. Mass mortality during metamorphosis to megalops in the seed production of mud crab Scylla serrata (Crustacea, Decapoda, Portunidae). Fisheries Science 68: 1226-1232.

LuppI, T.A.; E.D. SPIvAK \& K. ANger. 2001. Experimental studies on predation and cannibalism of the settlers of Chasmagnathus granulata and Cyrtograpsus angulatus Brachyura: Grapsidae. Journal of Experimental Marine Biology and Ecology 265: 29-48.

Mann, D.; T. Asakana; M. Pizzutto; C.P. Keenan \& I.J. Brock. 2001. Investigation of an Artemia based diet for larvae of the mud crab Scylla serrata. Asian Fisheries Science 14: 175-184.

Marasigan, E.T. 1999. Development of practical diet for growout of mud crab species Scylla serrata and $S$. tranquebarica, p. 187-195. In: C.P. Keenan \& A. Blackshaw (Eds). Mud crab Aquaculture. Canberra, Aciar Procedings, I+98p.

Marichamy, R. \& S. Rajapackiam. 2001. The aquaculture of Scylla species in India. Asian Fisheries Science 14: 231238.

Masuda, R. \& K. TsuKamoto. 1998. Stock enhancement in Japan: Review and perspective. Bulletin of marine science 62 : 337 358.

Moksnes, P.O.; R.N. Lipcius; L. Pihl \& J. Van Montfrans. 1997. Cannibal-prey dynamics in juveniles and postlarvae of the blue crab. Journal of Experimental Marine Biology and Ecology 215: 157-187.

O'ConNor, N. 2007. Stimulation of molting in megalopae of the Asian shore crab Hemigrapsus sanguineus: physical and chemical cues. Marine Ecology Progress Series 352: 1-8.

O'Connor, N. \& A.S. Gregg. 1998. Influence of potential habitat cues on duration of megalopal stage of the fiddler crab Uca pugnax. Journal of Crustacean Biology 18: 700-709.

Quinitio, E.T. \& F.D. Parado-Estepa. 2000. Transport of Scylla serrata megalopae at various densities and durations. Aquaculture 185: 63-71.

Rodriguez, E.M.; F.D. Parado-Estepa \& E.T. Quinitio. 2007. Extension of nursery culture of Scylla serrata (Forsskål) juveniles in net cages and ponds. Aquaculture Research 38: 1588-1592.

Secor, D.H.; A.H. Hines \& A.R. Place. 2002. Japanese Hatcherybased Stock Enhancement: Lessons for the Chesapeake Bay Blue Crab. Maryland, Sea Grant Publication, 46p.

Silva, U.A.T.; A. Ostrensky; R. Ventura; A.F. Santos \& W.A. Boeger. 2006. A produção de caranguejo-uçá em laboratório. Panorama da Aquicultura 16: 15-21.

Silva, U.T.A.; F.M. Ramos; R. Ventura; A. Coelho Neto; W.A. Boeger, \& A. Ostrensky. 2009. A produção de larvas de caranguejouçá em sistema de cultivo em mesocosmos. Panorama da Aquicultura 113: 24-28.

Simith, D. J. B. \& K. Diele. 2008. Metamorphosis of mangrove 
crab megalopae, Ucides cordatus (Ocypodidae): Effects of interspecific versus intraspecific settlement cues. Journal of Experimental Marine Biology and Ecology 362: 101-107.

Ventura, R.; U.T.A. Silva; G. Perbiche-Neves; A. Ostrensky; W.A. Boeger \& M.R. PIE. 2008. Larval cannibalism rates in the mangrove crab Ucides cordatus (Decapoda: Ocypodidae) under laboratory conditions. Aquaculture Research 39: 263 267.

Ventura, R.; U.A.T. Silva; K. Cottens; W.A. Boeger \& A. Ostrensky. 2010. Restocking Ucides cordatus (decapoda: ocypodidae): interespecific associations as a limiting factor to the survival of released recruits. Brazilian Journal of Oceanography 58 (3): 207-212.

Ventura, R.; U.A.T.Silva; A.Ostrensky; K.Cottens \& G. Perbiche-NeVEs. 2010. Survival of Ucides cordatus (Decapoda: Ocypodidae) megalopae during transport under different conditions of density and duration. Zoologia 27 (6): 845-847.

Zmora, O.; A. Findiesen; J. Stubblefield; V. Frenkel \& Y. Zohar. 2005. Large-scale juvenile production of the blue crab Callinectes sapidus. Aquaculture 244: 129-139.

Submitted: 25.XI.2009; Accepted: 26.XI.2010.

Editorial responsibility: Maria Lúcia Negreiros-Fransozo 